\title{
Curriculum Auditing: Embedment of Graduate Capitals in Ethiopian Undergraduate Engineering Programs' Harmonized Curricula
}

\author{
Tesfamariam Shimekit \\ Corresponding Author, PhD candidate at Addis Ababa University, \\ Department of Educational Planning and Management \\ Jeilu Oumer ( $\mathrm{PhD})$ \\ Associate Professor at Addis Ababa University Department of Educational Planning and Management
}

\begin{abstract}
Curriculum auditing is a method for ascertaining how and where employability competencies are embedded in curricula. The purpose of this study was to explore whether the undergraduate engineering harmonized curricula have embedded graduate employability competencies. The study employed a qualitative approach and considered six randomly selected public universities and 12 industries. Besides, two professional associations were also included purposively. The study participants were 12 department heads, two heads of professional associations, seven industries heads, and 18 long-time unemployed graduates. Data were collected by content analysis of the three undergraduate engineering programs' harmonized curricula and interviewing key informants. The main contribution of this work lies in showing the gaps of curricula in embedding the necessary employability capitals. The findings revealed that necessary graduate capitals and learning experiences employed for employability enhancement were not adequately embedded in electrical, civil, and, mechanical engineering harmonized curricula. Thus, undergraduate engineering curricula were not able to prepare graduates for the world of work. The study, therefore, recommended that universities should continually audit and revise their curricula to embed the necessary competencies by involving industries and professional associations.
\end{abstract}

Keywords: curriculum auditing, employability, employability enhancement, graduate capital, university

DOI: $10.7176 / \mathrm{JEP} / 12-22-05$

Publication date:August $31^{\text {st }} 2021$

\section{Introduction}

In this globalized and highly dynamic era, higher education graduates having a degree or diploma is not enough to be competitive in the labor market, productive at a workplace, and able to create a high-quality life. Graduates must have the skills, knowledge, and personal attributes which make them competitive in the labor market, productive in their career, and successful in their life. These, in turn, lead to organizational prosperity and national development i.e. the contribution of higher education to the economic prosperity of the country. Better quality of life and national development are what nations and societies expect as returns for the money they invest in higher education. Based on the assumption that the welfare of individuals and the competitive advantage of nations is a function of the knowledge, skills, and entrepreneurial passion of the labor force, even most developed countries such as the United Kingdom and Finland designed and implemented their employability policy (Boden \& Nedeva, 2010). Considering the demands of the labor market and incorporating them in higher education curriculum help to improve employability, achieve individual's quality of life, and national productivity. More specifically, employability can be considered in the curriculum by identifying and embedding relevant skills, knowledge, personal attributes in the curriculum; including different courses e.g. entrepreneurship in the curriculum; participating employers in the curriculum development; and including different employability enhancement strategies in the curriculum. As a result, graduates can make significant contributions to a nation's overall development (Atkins, 1999; Cranmer, 2006; Thodaro \& Smith, 2010).

The Ethiopian higher education system has grown and diversified rapidly over the past two decades driven by factors like population growth, an increment of upper-secondary enrollments, and rising needs for higher education. As a result, the higher education system has expanded to create more access for higher education, and currently, there are about 52 public universities and four private universities. Out of 52 public universities, 48 universities are governed under the Ministry of Science and Higher Education (MoSHE), and the rest four universities are supervised by different government ministries. All public universities are accountable to the government and are funded by the federal government. Previously, universities were classified based on their year of establishment as generation and there were four generations of universities. However, currently, universities are classified based on their current and future focus areas as research, universities of applied sciences, and comprehensive universities. The research universities comprise eight universities; applied universities contain 15 universities, and comprehensive universities include 21 universities (MoSHE, 2020). This 
classification has a direct implication on the focus and scope of programs universities provide.

Moreover, based on the recommendation of the current Ethiopia education road map (MoE, 2018), higher education is organized as an independent ministry called the Ministry of Science and Higher Education (MoSHE) by including the Technical and Vocational Education and Training (TVET) sub-sector. Besides, there are two independent organizations namely the Higher Education Strategy Center (HESC) and Higher Education Relevance and Quality Agency (HERQA). These organizations were established as regulatory bodies to the higher education system (FDRE, 2019). HESC led the undergraduate programs curricula harmonization and modularization task at the national level that has been implemented since 2014 and HERQA assures quality in the implementation of these harmonized curricula. Currently, engineering and technology programs are given in most universities because of the government's focus on science and technology areas as evidenced in the higher education expansion policy direction or long term plan (MoE \& MoCB, 2007). Due to the high enrollment of students in engineering and technology, the programs face various challenges among others shortage of qualified instructors and teaching-learning resources. Concerning the higher education curriculum, for all undergraduate programs nationally harmonized modular curricula are designed and implemented in all universities (ESC, 2013). Nevertheless, the implementation of harmonized modular curricula faced different challenges due to variations in institutional capacity, and capability (Olamo et al., 2019). These problems and challenges result in high graduate unemployment and low employability of engineering graduates. However, in Ethiopia, there is no trend of auditing a curriculum and revise it accordingly. The purpose of this study was to explore whether the harmonized curricula have embedded graduate employability competencies in selected undergraduate engineering programs.

\section{Review of Related Literature}

The concept of employability is elusive and difficult to conceptualize simply. Various studies (like Bennett et al., 2017; Tomlinson, 2017; Yorke \& Knight, 2007) tried to conceptualize employability and identify a different set of skills, competencies, and capitals needed to enhance graduate employability. For instance, Bennett et al. (2017) proposed a model of course provision in higher education, which included five elements: (1) disciplinary content knowledge; (2) disciplinary skills; (3) workplace awareness; (4) workplace experience; and (5) generic skills. This model goes some way towards including all the necessary elements to ensure a graduate achieves an optimum level of employability but is still missing some vital elements such as personal qualities and psychosocial elements. The second model is developed by Yorke \& Knight (2007). It is the USEM Model and the most well-known in the field of employability. USEM is a contraction for four interconnected parts of employability i.e. Understanding, Skills, Efficacy beliefs; and Meta-Cognition. The USEM model has strengths such as it relates employability with the actual teaching-learning process especially considering employability in curriculum. It creates an opportunity for how curriculum includes an assessment that enhances the student's efficacy and meta-cognition by relating with development of subject knowledge and professional skills that are transferable to the practice context that enhances the assessment in the curriculum. The major limitation of the USEM model is its difficulty to clarify what is meant by employability exactly to non-specialists in the fields such as students and parents. The third model is the DOTS Model. The DOTS model, among other things, consists of planned experiences designed to facilitate the development of decision learning, opportunity awareness, transition learning - including job searching and self-presenting skills, Self-awareness - in terms of interests, abilities, values, etc. The value of the DOTS model is its simplicity and the criticism is it is over-reliant on a mechanistic matching of person and environment and therefore underplays other critical issues such as social and political contexts. Moreover, the model has shortcomings when it is applied beyond careers education to the broader concept of employability. The fourth model is the Career EDGE model and It has five components i.e. career development learning, experience, degree of a subject, generic skill, and emotional intelligence. It is suggested that providing students with opportunities for them to access and develop everything on these five components and essentially, for reflecting on and evaluating these experiences, will result in the development of higher levels of self-efficacy, self-confidence, and self-esteem - the crucial links to employability. In this model generic skills are used to represent the skills that can be used in any discipline, and which can potentially be transferred to a range of contexts, in higher education or the workplace.

The skills agenda has guided how employability is enhanced at universities and how and why graduates succeed in the labor market. Further, several studies have been conducted to identify skills for specific professions such as engineering. For example, Zaharim et al. (2009) identified engineering employability skills required by employers in Asia (Malaysia, Japan, Singapore, and Hong Kong) by reviewing different articles, journals, papers, and reports. All in all, the study suggested that the engineering graduates should acquire and demonstrate a set of generic skills like communication skills, problem-solving, workplace literacy \& numeracy, Engineering problem solving decision making skills, engineering system approach, IT and computers skills, and interpersonal skills

However, there is still academic debate and employer analysis on what makes a graduate desirable to 
employers and what role higher education plays in making a graduate more desirable to the labor market. In this regard, the skills approach is criticized for its several limitations in preparing graduates for the labor market. Moreover, according to Holmes (2001), the skill agenda can be criticized for three reasons. First, the meaning of skill can be different in the discourse of academics and employers. Second, the employers do not want skills only they rather need the employees to perform efficiently and to possess certain attributes. Third, the - skills agenda provides little help in understanding the complexity of post-graduation career trajectories, for it assumes that the process of gaining a job is simply a matter of matching skills required and skills possessed. Moreover, Benbow and Hora (2018) also identified some critics of the skills approach. The first critique is related to the techniques used to generate lists of employability skills since employability skill lists are developed by panels of scholars and experts with little input from stakeholders with firsthand experience of education and workforce development. The second critique employability skill lists are not linked with the occupational, organizational, and socio-cultural contexts in which such competencies are cultivated, assigned value, and deployed. A third critique of skill lists is that treating skills as distinct, individualistic traits conveys an inaccurate picture of how skills, knowledge, and abilities are valued in practice and internalized via cognitive processes. Finally, the employability discourse has been critiqued for equating employment with students' possession of the "right" skills, thereby ignoring the role business cycles, corporate hiring practices, social networks, cultural capital, and structural inequalities play in influencing people's access to education and job opportunities (Holmes, 2013; McQuaid \& Lindsay, 2005).

To fill the limitations of the skills approach in employability enhancement, models that include various issues like behavior/performance, identity, social, and cultural assets other than skills are introduced on the issue of graduate employability. Among others graduate identity approach and graduate capital model are exemplary approaches that shift the conceptualization of the employability skill only approach to a more comprehensive approach. The purpose of the graduate identity approach is to provide a general rationale for curriculum design, the selection, and the development of teaching and assessment activities. The identity is described by using two concepts i.e. interpretation of activity as performance-of - kind and emergent identity arises from the interaction between claim/disclaim by the individual and affirmation/dis-affirmation by significant others (Holmes, 2001). The second model is the graduate capital Model that conceptualizes graduate employability in a very comprehensive way by including different assets. According to Tomlinson (2017), graduate capital is defined as "key resources that confer benefits and advantages onto graduates" (p.339) and identified five forms of graduate capitals i.e. human capital, social capital, cultural capital, identity capital, and psychological capital. More clearly, human capital refers to the knowledge and skills, which graduates acquire that are a foundation of their labor market outcomes. Social capital is the sum of social relationships and networks that help mobilize graduates' existing human capital and bring them closer to the labor market and its opportunity structures. Cultural capital can be considered as the formation of culturally valued knowledge, dispositions, and behaviors that are aligned to the workplaces that graduates seek to enter. Identity capital can be understood as the level of personal investment a graduate makes towards the development of their future career and employability. Psychological capital is a potentially significant form of capital as it is based on the psychosocial resources which enable graduates to adapt and respond proactively to inevitable career challenges (Tomlinson, 2017).To enhance the employability of graduates these skills, competencies, and capitals must be identified based on the needs of the current and future labor market and adequately embedded in the curriculum.

After identifying the necessary competencies for employability enhancement, the main issue is how and where competencies are embedded in the curriculum. Various studies (such as Chadha, 2006; Maria et.al. 2020; McWilliams\& Allan,2014; and Yorke \& Knight,2006) identified different approaches to embed the necessary competencies in the curriculum. Mores specifically, Yorke \& Knight (2006) further identified different approaches to embed employability-related learning in the curriculum. The approaches are not 'one size fits all Learning, employability through the whole curriculum, employability in the core curriculum, work-based or work-related learning interspersed within the curriculum, employability-related modules within the curriculum, work-based or work-related learning in parallel with the curriculum. Further, Yorke \& Knight (2006) emphasize that teaching, learning, and assessment techniques compatible with curricular intents are required to support good learning and employability intentions.

Curriculum Auditing provides an opportunity to assess how and where employability-related learning is incorporated into curricula. Based on the result of the curriculum auditing, and take corrective measures like curriculum revision. Moreover, Maria, et .al. (2020) study practical, multidisciplinary methods employed to embed employability skills in a new postgraduate (PGT) Engineering course at the University of Bath. The study identifies specific methods such as design consideration i.e. embedding employability skills in the curriculum, curriculum alignment that focuses on the coherence of teaching, learning, and assessment; the need for integrative learning, and the need for experiential learning.

Various studies (for example, Armah and Westhuizen 2020; Mashiyi, 2015; and Shivoro et al., 2017) have also conducted Africa about embedding various employability skills such as digital capability, graduate 
attributes, and values in different undergraduate curricula. The findings indicated limitations in incorporating the necessary graduate competencies in the curriculum. Ethiopia also studies have conducted on different issues like engineering curriculum development (Mesfin, 2016) and implementation, engineering graduates unemployment (Tamiru, 2017). The findings of these studies indicated that low involvement of teachers and industries in curriculum development, unsound curriculum implementation, and education-job mismatch is both vertical and horizontal and affects more than a third of the graduates (41.5 percent). However, previous studies did not well addressed the embedment of necessary graduate capitals in undergraduate harmonized curricula and the current study fill this research gap.

\subsection{Methodology}

Study Approach: The current study employed a qualitative study approach. Bogdan and Biklen (2007) define qualitative research as "an approach to social science research that emphasizes collecting descriptive data in natural settings, uses inductive thinking, and emphasizes understanding the subjects point of view" (p. 274). Since the purpose of this study was to realize the embedment of the necessary capitals in the three undergraduate engineering programs' curriculum, the qualitative research method is quite fruitful to deeply understand the social processes i.e. employability enhancement in its context (Denzin \& Lincoln, 2005).

Study Participants: The study considered six randomly selected public universities, purposively selected 12 industries and 2 professional associations. All participants of the study were selected purposively and include 12 department heads, two heads of professional associations, and seven industries heads. Moreover, 18 long-time unemployed graduates (2-3years) were also included by using snowball sampling from three regions and graduated in six selected universities.

Data Collection Instrument and Procedure: The current study primarily employed two types of data collection instruments to get the whole picture of the issue under consideration. The interview guides were prepared by considering different empirical and theoretical evidence and validated by two individuals who have expertise in the area. Besides, the data was triangulated by interviews, curriculum auditing, and document review. Interview guides were used for department heads, long-time unemployed graduates, industry leaders, and professional association heads. The interview was made based on the consent of participants and recorded. The recorded data were transcribed and made ready for analysis.

Data Analysis: The data collected through the interview was analyzed by employing the thematic analysis technique. Besides, content analysis was done on three harmonized engineering programs (i.e. Civil, electrical, and mechanical) curricula for the purpose of curriculum auditing. Moreover, Nvivo 11 software was employed to analyze the collected data.

\section{Result and Discussion}

Various studies (Cole \& Tibby, 2013; Dacre-Pool and Sewell, 2007; and Yorke \& Knight, 2007) indicated that graduate competencies and learning experiences should be embedded in the curriculum to properly prepare graduates for the labor market. Considering this fact, the current study tried to see whether employability competencies and learning experiences were embedded in the curricula of the three engineering undergraduate programs namely civil, mechanical, and electrical engineering. To achieve this purpose, curriculum auditing was done on the nationally harmonized curricula of the three engineering programs. Even though curriculum auditing is broad concept for the purpose of this study, it is defined as a process that offers a way of testing how and where employability-related learning is incorporated into written curricula (Yorke \& Knight, 2007). Curriculum auditing has many advantages and it is a powerful tool in achieving effectiveness and efficacy of the education system (Bhatti, 2015). In the current study, the curriculum audit considered the only written curriculum. Moreover, because there is no specific standard tool or criteria to audit a curriculum regarding the incorporation of employability-related learning, the researcher employed self- prepared auditing tool. The tool was prepared by considering the advices from different theories and models of employability that were reviewed in chapter two (See Table 1).

Table1 Criteria for Curriculum Audit

\begin{tabular}{|l|l|l|}
\hline Theories & $\begin{array}{l}\text { Suggestions from the model. The } \\
\text { curriculum should contain/include: }\end{array}$ & Criterion derived from the theory \\
\hline $\begin{array}{l}\text { A Model of Course } \\
\begin{array}{l}\text { Provision in HE } \\
\text { Bennett et al., }\end{array} \text { - }\end{array}$ & $\begin{array}{l}\text { Work place awareness, experience, and } \\
\text { generic skill }\end{array}$ & $\begin{array}{l}\text { Does the curriculum contain various } \\
\text { aspects that can increase workplace } \\
\text { awareness of students? }\end{array}$ \\
& $\begin{array}{l}\text { Does the curriculum contain various } \\
\text { aspects that can increase work } \\
\text { experience of students? } \\
\text { Does the curriculum contain various } \\
\text { generic skills? }\end{array}$ \\
\hline
\end{tabular}




\begin{tabular}{|c|c|c|}
\hline Theories & $\begin{array}{l}\text { Suggestions from the model. The } \\
\text { curriculum should contain/include: }\end{array}$ & Criterion derived from the theory \\
\hline $\begin{array}{lll}\text { USEM } & & \text { Model } \\
\text { (Cole \& } & \text { Tibby, } \\
2013) & & \end{array}$ & $\begin{array}{l}\text { Assessment that enhances the student's } \\
\text { efficacy and meta-cognition by relating } \\
\text { with development of subject knowledge } \\
\text { and professional skills those are } \\
\text { transferable to the practice context that } \\
\text { enhances the assessment in curriculum the } \\
\text { assessment. }\end{array}$ & $\begin{array}{l}\text { - Does the curriculum include assessment } \\
\text { techniques enhances the student's } \\
\text { efficacy and meta-cognition by relating } \\
\text { with development of subject knowledge } \\
\text { and professional skills? }\end{array}$ \\
\hline $\begin{array}{lr}\text { DOTS } & \text { Model } \\
\text { (Yorke \& } & \text { Knight, } \\
\text { 2007) } & \end{array}$ & 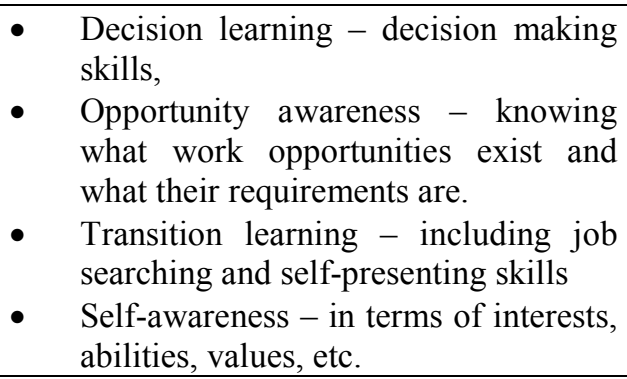 & $\begin{array}{l}\text { - Does the curriculum encourage } \\
\text { decision making skills? } \\
\text { - Does the curriculum provide } \\
\text { opportunity awareness? } \\
\text { - Does the curriculum provide transition } \\
\text { learning? }\end{array}$ \\
\hline $\begin{array}{l}\text { CareerEDGE } \\
\text { Model-The key to } \\
\text { Employability } \\
\text { (Dacre- Pool \& } \\
\text { Sewell, 2007) }\end{array}$ & $\begin{array}{l}\text { Career development learning, Experience } \\
- \text { work and life, Degree of subject } \\
\text { knowledge, understanding, and skills, } \\
\text { Generic skills, Emotional intelligence, } \\
\text { Reflection and Evaluation, Self-efficacy, } \\
\text { Self-esteem, and Self-confidence }\end{array}$ & $\begin{array}{l}\text { - Does the curriculum develop emotional } \\
\text { intelligence? } \\
\text { Does the curriculum encourage } \\
\text { reflection and evaluation? } \\
\text { - Does the curriculum encourage self- } \\
\text { efficacy, Self-esteem, and self- } \\
\text { confidence? }\end{array}$ \\
\hline $\begin{array}{l}\text { The 'graduate } \\
\text { identity' approach } \\
\text { (Holmes, 2001) }\end{array}$ & $\begin{array}{l}\text { The main purpose of the graduate identity } \\
\text { approach is to provide a general rationale } \\
\text { for curriculum design, and the selection } \\
\text { and development of teaching and } \\
\text { assessment activities. }\end{array}$ & $\begin{array}{l}\text { - Does the curriculum encourage } \\
\text { graduate identity? }\end{array}$ \\
\hline $\begin{array}{l}\text { Graduate capital } \\
\text { model (Tomlinson, } \\
\text { 2017) }\end{array}$ & $\begin{array}{l}\text { Human capital, social capital,_cultural } \\
\text { capital,_identity capital, and psychological } \\
\text { capital. }\end{array}$ & $\begin{array}{l}\text { - Does the curriculum include key } \\
\text { resources that confer benefits and } \\
\text { advantages onto graduates? }\end{array}$ \\
\hline $\begin{array}{l}\text { An educational } \\
\text { framework for } \\
\text { entrepreneurship, } \\
\text { internationalization, } \\
\text { and innovation } \\
\text { (Christina \& Tine } \\
(2017)\end{array}$ & $\begin{array}{l}\text { the educational concept of innovation } \\
\text { pedagogy with a better attention on } \\
\text { entrepreneurship education and } \\
\text { internationalization into the curricula of } \\
\text { universities is an important step towards } \\
\text { becoming more entrepreneurial }\end{array}$ & $\begin{array}{l}\text { - Does the curriculum include innovation } \\
\text { pedagogy entrepreneurship education } \\
\text { and internationalization }\end{array}$ \\
\hline
\end{tabular}

Based on these criterions the three harmonized curricula were audited as follows,

\section{A. Civil Engineering Harmonized Curriculum (2014)}

The harmonized civil engineering curriculum is composed of 24 modules with a total of 307 Ethiopian Credit Transfer System (EtCTS) credit points in the program. The program aims to produce professionals equipped with relevant knowledge, skills, and attitude that would contribute to the development of the country.

The curriculum contains some aspects that can increase workplace awareness of students such as internship: industry practice, entrepreneurship, and site visit report. These learning experiences not only used to increases the students' workplace awareness but also help to increase the work experience of students. Regarding the generic skills, the civil engineering curriculum contains various generic skills which can be employed in the world of work. These skills were a team work, leadership, business skills, critical reasoning, effective communication, and interpersonal skills.

With respect to assessment, different assessment techniques were included in the curriculum. The assessment contains both formative (50\%) and summative assessments $(50 \%)$ techniques. Formative assessment comprises at least five different assessment techniques (to name a few, quizzes, assignments, reports $\&$ projects) of assessment and summative assessments were done as examination. Besides, there is also evaluation made by employers during industry placement. Most of these assessment techniques were not helpful to enhance the 
student's efficacy and meta-cognition by relating with development of subject knowledge and professional skills. However, assessment techniques like projects, reports of workshops, and employer evaluation are useful in developing student's efficacy and employability.

In relation to decision making skill, even though it is a very important skill in every career, the curriculum did not give enough emphasis on it. It is only indicated as civic skills employed to make accurate decision making. As for opportunity awareness, the curriculum did not include organized experiences that enable students to know what work opportunities exist in the labor market and what requirement these work opportunities are needed. However, students may get some information on different opportunities during their industry placement. Even the information students obtain from industry placement is not enough to get the complete picture of industries in the labor market. Regarding, transition learning which includes job searching and self-presenting skills, the curriculum included the issue of job searching in industry practice and entrepreneurship module. As a result, students are expected to search for a job (i.e., Mock job searching) and present written report about the job searching process and information about the job. This helps the students to make a good transition from education to work which in turn has positive impact on their employment and future career success.

Regarding emotional intelligence, even though emotional intelligence is important to work with different people successfully, there is no any experience embedded to develop the capacity of students to be aware, control, and express their emotion. In relation to this, Dacre- Pool and Sewell (2007) indicated that faculty will help students become well-rounded graduates by implementing emotional intelligence theory and exercises. Therefore, the curriculum should have incorporated different learning experiences and exercises that help students to develop emotional intelligence. Concerning reflection and evaluation, though the curriculum tried to create opportunities for the students to gain the necessary skills, knowledge, understanding, there is no anyway of assuring the level of accusation of these skills, knowledge, understanding. This would be done by including different learning experiences that enable the students to reflect on their progress and evaluate themselves. Especially, for employability development, reflection and evaluation are very important because the student can identify what is already acquired and expected to be acquired. For instance, Dacre- Pool and Sewell (2007) recommended the inclusion of Personal Development Planning (PDP) experience in teaching and learning because PDP has a strong link with enhancing the employability of graduates.

Another aspect to enhance the employability of graduates is encouraging self-efficacy, self-esteem, and self-confidence of graduates. These three constructs are important because they provide a crucial link between knowledge, understanding, skills, experience and personal attributes, and employability (Dacre- Pool \& Sewell, 2007). Self-efficacy can be achieved by using experiences like mastery experiences, vicarious experiences (e.g. experience shearing with successful alumina), and social persuasion (e.g. influencing others and get their full trust). In this regard the harmonized civil engineering curriculum expected students to work in the industry and this helps to build students self -efficacy. However, vicarious experiences and social persuasion were not included in the curriculum as an organized learning experience.

Pertaining to the graduate capitals, the harmonized civil engineering curriculum gave more focus on human capital. More specifically, the curriculum focuses on knowledge of the subject matter, accusation of some soft skills, and their relationship with world of work. However, less emphasis is given to the other four employability capitals i.e. social, cultural, identity, and psychological capitals. These capitals can be included in different ways in the curriculum like by including learning experiences that enable to create social networking, aware of a different culture, help students to develop civil engineer identity, and developing resilience that enable to work in various conditions and to face various challenges including long-time unemployment.

With reference to innovation pedagogy, entrepreneurship education, and internationalization the harmonized civil engineering curriculum lacks various issues. The curriculum did not put various experiences i.e. methods and tools that help students to participate in the innovation creating process such as applied researches and group interactions, entrepreneurial and international activities. However, the curriculum emphasizes for entrepreneurship by including course entrepreneurship for engineers which can increases students awareness about entrepreneurship. But the curriculum does not include learning experiences that enable students to participate in task-oriented skills acquisition such as small business development and management. Finally, the curriculum also lacks the inclusion of internationalization by various activities like encouraging intercultural skills, global awareness, and the ability to interact in a global setting. These can be done through intercultural training, student/staff mobility, credit/degree mobility, and international networks.

\section{B. Mechanical Engineering Harmonized Curriculum (2014)}

The harmonized mechanical engineering curriculum is composed of 39 modules with a total of 301 EtCTS credit point in the program. The main goal of the program is to enable graduates to meet the challenges of the engineering profession in a rapidly changing environment that exists in a developing country like Ethiopia. Besides, the program aims to develop future professionals with problem identification/solving skills and positive attitudes to serve the society and equipped with relevant knowledge and skills, who would contribute to the development of the country. 
Like the civil engineering curriculum, the mechanical engineering curriculum also contains some aspects that can increase workplace awareness of students such as an industrial internship program. The industrial internship program is employed to provide broad-based engineering profession understanding in a rapidly changing environment that exists in and entrepreneurship for engineers as a course. These activities not only used to increases the students' workplace awareness but also help to increase the work experience of graduates. Further, the mechanical engineering curriculum contains various generic skills used in the world of work. These skills were technical, analytical/computational skills, reasoning and problem solving skills team working, leadership, business skills, critical reasoning effective communication, and interpersonal skills, communication skills, and managerial or behavioral skills.

Regarding assessment, the mechanical engineering curriculum follows the similar approach with civil engineering i.e. using both formative and summative assessments techniques and evaluation made by employers during industry placement. However, this technique could not enhance the student's efficacy and meta-cognition by relating with development of subject knowledge and professional skills.

Concerning the decision making skills like civil engineering curriculum, the mechanical engineering curriculum also does not give emphasis to the decision -making skill. It is only indicated in some courses (namely, operation research \& maintenance and installation of machinery) as skills. On the subject of opportunity awareness, except industry placement, the curriculum did not include organized experiences that enable students to know what work opportunities exist in the labor market and what requirements are required to enroll themselves in these work opportunities. Regarding transition learning which includes job searching and self-presenting skills, the curriculum did not include the issue of job searching in it. As a result, students may face challenges in job searching and self-presenting skills in the labor market.

Like the civil engineering curriculum, the mechanical engineering curriculum also did not include emotional intelligence in the curriculum even though emotional intelligence is crucial. Concerning to reflection and evaluation, similar to the civil engineering curriculum, the mechanical engineering curriculum also tried to create the opportunities for the students to gain the necessary skills, knowledge, understanding. However, there is no anyway of assuring the level of accusation of the necessary skills, knowledge, understanding because of absence of reflection and evaluation as the assessment strategies.

In relation to encouraging of self-efficacy, self-esteem, and self-confidence of graduates the harmonized mechanical engineering curriculum expected students to work experience in the industry and this helps to build students self-efficacy. However, vicarious experiences, and social persuasion were not included in the curriculum as organized learning experience.

Like the civil engineering curriculum, the harmonized mechanical engineering curriculum gives more focus on human capital more specifically knowledge of the subject matter, various skills, and their relation with work. However, less emphasis is given for the other four employability capitals i.e. social, cultural, identity, and psychological capitals.

Similar to the civil engineering curriculum, the mechanical engineering curriculum did not put various experiences i.e. methods and tools that help students to participate in the innovation creating process such as applied researches and group interactions, entrepreneurial and international activities. The mechanical engineering curriculum emphasizes on entrepreneurship by including a course, entrepreneurship for engineers, which can increases students' awareness about the entrepreneurship. Alike to the civil engineering curriculum, the mechanical engineering curriculum did not encourage students to participate in task-oriented skills acquisition such as small business development and management. Finally, the curriculum also lacks the inclusion of internationalization by various activities like encouraging intercultural skills, global awareness, and the ability to interact in the global setting. These can be done through intercultural training, student/staff mobilities, credit/degree mobility, and international networks.

\section{Electrical Engineering Harmonized Curriculum (2014)}

The harmonized civil engineering curriculum is composed of 37 modules with a total of 302 EtCTS credit points in the program. The program aims to cater to the demand of innovative, highly skilled, practice oriented, entrepreneur, and ethical man power in the various fields of electrical and computer engineering such as power engineering, industrial control engineering, communication engineering, and computer engineering.

Like the civil engineering and mechanical engineering curricula, the electrical engineering curriculum also contains some aspects that can increase workplace awareness of students such as industrial internship and engineering entrepreneurship as a course, and semester project. These activities are not only used to increases the students' workplace awareness but also helps to increase the work experience of graduates. Further, the Electrical engineering curriculum contains various generic skills used in the world of work. These skills were, reasoning and problem solving skills, team working, working independently, leadership, business skills, learning life-long, and internationalization.

Regarding the assessment strategies, the electrical engineering curriculum follows the similar approach with civil engineering and mechanical engineering i.e. using both formative and summative assessments techniques 
and evaluation made by employers during industry placement. In contrast to the two curricula, the electrical engineering curriculum introduced assessment techniques such as holistic evaluation, individual reflection, and presentation as assessment techniques. These techniques could help to enhance the student's efficacy and metacognition by relating with development of subject knowledge and professional skills.

Differently from the two curricula, the electrical engineering curriculum did not encourage the decision making skills of students in any course in the curriculum. Regarding opportunity awareness, except industry placement, the curriculum did not include organized experiences that enable students to know what work opportunities exist in the labor market and what requirements are required to enroll themselves in these work opportunities. In relation to transition learning which includes job searching and self-presenting skills, the electrical engineering curriculum also did not included the issue of job searching in it. As a result, graduates may face challenges job searching and self-presenting skills in the labor market.

Analogous to the two curricula, the electrical engineering curriculum also did not include emotional intelligence in the curriculum even though emotional intelligence is crucial. Concerning reflection and evaluation, similar to the civil and mechanical engineering curricula, the electrical engineering curriculum also tried to create the opportunities for the students to gain the necessary skills, knowledge, and understanding. Unlike the two curricula, the electrical engineering curriculum put a reflection as assessment method. This helps students to identify their level of the acquisition of employability skills.

Concerning encouraging of self-efficacy, self-esteem, and self-confidence of graduates, the harmonized electrical engineering curriculum expected students to get work experience in the industry and this helps to build students self -efficacy. However, vicarious experiences and social persuasion were not included in the curriculum as organized learning experiences similar to the two curricula.

Like the civil and electrical engineering curriculum, the harmonized electrical engineering curriculum gives more focus on human capital more specifically knowledge of the subject matter, various skills, and their relation with work. However, less emphasis is given for other four employability capitals i.e. social, cultural, identity, and psychological capitals

Like the civil and mechanical engineering curriculum, the electrical engineering curriculum did not put various experiences i.e. methods and tools that help students to participate in the innovation creating process such as applied researches and group interactions, entrepreneurial and international activities. The electrical engineering curriculum emphasizes on entrepreneurship by including a course entrepreneurship for engineers which can increases students awareness about the understanding of entrepreneurship. Similar to the civil and mechanical engineering curriculum, the electrical engineering curriculum did not encourage students to participate in task-oriented skills acquisition such as small business development and management. Finally, the electrical engineering curriculum also lacks the inclusion of internationalization by various activities like encouraging intercultural skills, global awareness, and the ability to interact in global setting. These can be done through intercultural training, student/staff mobility, credit/degree mobility, and international networks.

Besides, the interview with department heads, industry heads, professional association heads, and longtime unemployed graduates also supports the curriculum audit findings. The main gaps in embedding the necessary graduate capitals into the curricula were observed in curriculum design and implementation stages. More specifically, the gaps were identifying the necessary competencies and considering them in the curriculum, low involvement of industries and professional associations in the teaching-learning process, lack of vertical and horizontal integration, lack integration of work-based and practical oriented learning, and less use of assessment techniques that can measure students overall competencies, skills, individual behavior. In this regard, one of the department head and a longtime unemployed graduate put their opinion as follow,

The curricula in undergraduate engineering programs have not incorporated the necessary competencies that make students productive in the current and future labor market. The curriculum gives more emphasis to competencies related to theoretical understandings such as knowledge and understanding. However, the current labor market requires various soft and hard skills, social and cultural assets (Department Head \# 5, 2020).

The university teaching-learning approach requires me to memorize different theories and principles and employ them to solve engineering related problems. However, when I come to the labor market to find a job or create my business, the competencies demanded by the labor market are different from what $I$ learned in the university. The labor market requires hands-on skills, communication skills, technological skills, financial skills, and the ability to work with various cultures and social contexts. These necessary competencies should have incorporated into the curricula (Long-time unemployed\#4, 2020).

\section{Discussion}

The three harmonized curricula have strengths in creating opportunities for workplace awareness of students such as industrial internship and engineering entrepreneurship as a course, and semester project. Moreover the 
three curricula contain various generic skills employed in labor market but there were gaps in including different capitals like social, culture, psychological and identity. Regarding assessment techniques, the three curricula have limitations in embedding different assessment techniques that enhance the student's efficacy and metacognition by relating with the development of subject knowledge and professional skills. Further, the three curricula have gaps in including opportunity awareness, transition learning emotional intelligence, vicarious experiences, and social persuasion in the curricula. Moreover, these three curricula did not encourage students to participate in task-oriented skills acquisition such as small business development and management. Finally, the three curricula have also weakness in the inclusion of internationalization by various activities like encouraging intercultural skills, global awareness, and the ability to interact in global setting. Therefore, these three written curricula did not properly incorporate the necessary competencies and learning experiences that help to enhance students' employability.

Furthermore, the curriculum auditing of the three nationally harmonized curricula showed that graduate employability competencies and learning experience were not embedded in the curriculum in a way that enhances the employability of graduates. This finding is very important because it indicated that the engineering curricula are not able to prepare employable graduates for the current and future labor market. These findings are in agreement with various studies like Bridgstock (2009), Bhatti (2015), Rowe \& Zegwaard (2017), and Støren, \& Aamodt, (2010).

\section{Conclusion and Recommendations}

In conclusion, the three undergraduate engineering programs' curricula have not incorporated the necessary competencies that prepare graduates for current and future work and life. Based on this, the study made some recommendations. Universities should continually audit and revise their curricula to embed the necessary competencies by involving industries and professional associations. Second, the university teaching, learning, and assessment approaches should consider the acquisitions of employability competencies. Third, the curriculum should contain learning experiences that create opportunities for the students to get practical and work-based orientation. Finally, the curriculum should also emphasize social, cultural, and psychological assets that enable the students to tackle various obstacles in the dynamic and competitive labor market.

Author Contributions: The authors have contributed equally to this work. All authors have read and agreed to the published version of the manuscript.

Funding: This research received no external funding.

Acknowledgments: We want to thank the anonymous referees who have helped to improve substantially the paper with their comments and suggestions. We are very grateful for all the support received by sample universities and industries.

\section{Reference}

Armah,J.K and Westhuizen, V.D.(2020). Embedding Digital Capability into the Higher Education Curriculum: The Case of Ghana. Universal Journal of Educational Research 8(2), 346-354.

Atkins, M. J. (1999). Oven - ready and self - basting: Taking stock of employability skills. Teaching in Higher Education, 4(2), 267-280.

Bennett, D., Knight, E., Divan, A., Kuchel, L., Horn, J., van Reyk, D., \& Burke da Silva, K. (2017). How do research-intensive universities portray employability strategies? A review of their websites. Australian Journal of Career Development, 26(2), 52-61. https://doi.org/10.1177/1038416217714475

Bhatti, A.J. (2015).Curriculum Audit: An Analysis of Curriculum Alignment at Secondary Level In Punjab. Doctoral desertion, International Islamic University. http://prr.hec.gov.pk/jspui/bitstream/123456789/6775/1/Abdul_Jabbar_Education_IIU_2015.pdf.

Boden, R., \& Nedeva, M. (2010). Employing discourse: Universities and graduate "employability". Journal of Education Policy, 25(1), 37-54.

Bogdan, R.C., \& Biklen, S.K. (2007). Qualitative research for education: An introduction to theories and methods (5th ed.). Boston: Pearson Education

Bridgstock, R. (2009). The graduate attributes we've overlooked: enhancing graduate employability through career management skills. Higher Education Research \& Development, 28 (1), 31-44. DOI: $10.1080 / 07294360802444347$

Chadha,D .(2006). A curriculum model for transferable skills development, Engineering Education, 1(1), 19-24.

Christina,S, \& Tine, L.(2017). Boosting the employability of students and staff at European higher education institutions: An educational framework for entrepreneurship, internationalization and innovation. DOI: http://dx.doi.org/10.4995/HEAd17.2017.5460.

Cole, D \& Tibby, M.(2013). Defining and Developing your Approach to Employability: A frame work to Higher Education Institutions. The Higher education Academy (HEA).Retrieved at https://www.advance-he.ac.uk/.

Cranmer, S. (2006). Enhancing graduate employability: Best intentions and mixed outcomes. Studies in Higher 
Education, 31(2), 169-184.

Dacre- Pool, L.\& Sewell, P.(2007).The key to employability: Developing a practical model of graduate employability. Education + Training,49 (4),DOI.10.1108/00400910710754435.

Denzin, N.K., \& Lincoln, Y.S. (2005). Introduction: The discipline and practice of qualitative research. In N.K. Denzin \& Y.S. Lincoln (Eds.), The sage handbook of qualitative research (2nd ed.). Thousand Oaks, CA: Sage.

Education Strategy Center(ESC).(2016). A Study on alumni of Ethiopian higher education institutions. Unpublished Study. Addis Ababa.

Federal Democratic Republic of Ethiopia.(2019). Higher Education Proclamation, No. 1152/2019. Addis Ababa. Federal Negarit Gazeta.

Holmes, L. (2001). Reconsidering graduate employability: The "graduate identity" approach. Quality in Higher Education, 7(2), 111-119. Retrieved at https://doi.org/10.1080/13538320120060006

Maria, V.;Tom. R; Ghislai D.; David, S.; Jo, H. ;Yvonne, M.; \& Sally, C.(2020). Embedding employability and transferable skills in the curriculum: a practical, multidisciplinary approach, Higher Education Pedagogies, 5:1, 247-266, DOI: 10.1080/23752696.2020.1816846 1

Mashiyi, F.N.(2015). Embedding Graduate Attributes in to the Foundation Program: Reflections On Process And Product. South African Journal of Higher Education. 29 (1), 181-197.

McWilliams, R. and Allan, Q. (2014). Embedding Academic Literacy Skills: Towards a Best Practice Model. Journal of University Teaching \& Learning Practice, 11(3), 1-22.

Mesfin, S. (2016). The Curriculum Development Process of the New Engineering Education Program and Its Practices in Ethiopia: The Case of Three Higher Engineering Education Institutions. Unpublished Ph.D. Thesis, Addis Ababa: Addis Ababa University.

MoE\&MoCB.(2007).Undergraduate and Graduate degree programs mix and student placement in the expanding higher education system in Ethiopia. A policy white paper.

MoE. (2015). Education sector development program v(ESDP-V):2015/2016 -2019/2020. program action plan $(P A P)$. Addis Ababa: Ministry of Education.

MoE.(2018). Ethiopian Education Development Roadmap (2018-30): An integrated Executive Summary. Draft for Discussion. Addis Ababa, Ethiopia.

MoSHE .(2020).Differentiating the Higher Education System of Ethiopia. Addis Ababa, Ethiopia.

Olamo, T. G., Mengistu, Y. B., and Dory, Y. A. (2019). Challenges Hindering the Effective Implementation of the Harmonized Modular Curriculum: The Case of Three Public Universities in Ethiopia. Creative Education, 10, 1365-1382.

Rowe, D.A., \& Zegwaard, E.K.(2017). Developing graduate employability skills and attributes: Curriculum enhancement through work-integrated. Asia-Pacific Journal of Cooperative Education, 18 (2), 87-99.

Shivoro, R., Shalyefu, R., \& Kadhila, N. (2017). Embedding graduate employability attributes in management sciences curricula: A case of two Namibian universities. Journal of Teaching and Learning for Graduate Employability, 8(1), 123-136.

Støren, L.A., \& Aamodt, O.P. (2010).The quality of higher education and employability of graduates. Quality in higher education, 16 (3), 297-313.

Tamiru, J. (2017). Exploring Employment Status and Education-Job Match among Engineering Graduates in Ethiopia: Policy Implications. IJAHE, 1-25.

Todaro, P.M. \& Smith, C.S.(2009). Economic Development (10 $0^{\text {th }}$ edition). USA: Pearson Education.

Tomlinson, M. (2017). Forms of graduate capital and their relationship to graduate employability. Education and Training, 59(4), 338-352.

Yorke,M \& Knight, T.P.(2006).Embedding employability into the curriculum. Learning and Employability Series 1. The Higher Education Academy.

Zaharim , A., Mdyusoff,Y.,Zaidi omar, M., Mohamed, A.,\& Muhamad,N.(2009). Engineering employability skills required by employers in Asia. Proceedings of the $6^{\text {th }}$ WSEAS international conference on engineering education. Retrieved at https://www.researchgate.net/publication/228975976 